\title{
Hydrodynamic and Chemical Conditions during the Onset of a Red-Tide Assemblage in an Estuarine Upwelling Ecosystem
}

Alvarez-Salgado XA, Figueiras FG, Villarino ML, Pazos Y

XA Alvarez-Salgado $(\varangle) \cdot$ FG Figueiras $\cdot$ ML Villarino

CSIC, Instituto de Investigacións Mariñas, Eduardo Cabello 6, E-36208 Vigo, Spain Y Pazos

XUGA, Centro de Control de Calidade do Medio Mariño, Peirao de Vilaxoan, E36611 Villagarcia de Arousa, Spain

email: xsalgado@iim.csic.es

tel: +3486231930

fax: +34 86292762 
Abstract The hydrodynamics and nitrogen/silicon biogeochemistry accompanying the development of a red-tide assemblage were examined in the Ría de Vigo (northwest Spain), a coastal embayment affected by upwelling, during an in situ diel experiment in September 1991. Despite a low N:Si molar ratio (0.5) of nutrients entering the surface layer, which was favourable for diatom growth, the diatom population began to decline. Limited $\mathrm{N}$-nutrient input, arising from moderate coastal upwelling in a stratified water column, restricted net community production $\quad(\mathrm{NCP}=$ $630 \mathrm{mg} \mathrm{C} \mathrm{m} \mathrm{d}^{-2}$ ). In addition, light-limitation of gross primary production (GPP= $1525 \mathrm{mg} \mathrm{C} \mathrm{m}^{-2} \mathrm{~d}^{-1}$ ) was observed. The relatively high $f$-ratio (= NCP/GPP) recorded (0.41, characteristic of intense upwelling conditions) would have been as low as 0.15 if GPP had not been limited by light intensity. Temporal separation of carbohydrate synthesis during the photoperiod from protein synthesis in the dark could be inferred from the time-course of the $\mathrm{C}: \mathrm{N}$ ratio of particulate organic matter. Severe lightlimitation would lead to diatom collapse were they not able to meet all their energy requirements during the hours of darkness. Under the hydrodynamic, nutrient and light conditions during the experiment, an assemblage of red-tide forming species began to develop, aided by their ability to migrate vertically and for use of carbohydrate synthesis during the light in surface waters and protein synthesis during the dark at the 4 m-deep pycnocline. Thermal stratification, reduced turbulence, intense nutrient mineralization, and the limited nitrogen input through moderate upwelling were all favourable to the onset of a red-tide assemblage. 


\section{Introduction}

Studies on the ability of red-tide organisms for vertical migration and their ecological advantage in stratified waters began at the beginning of this century (Hasle 1950 and references therein) and have continued to the present day (Blasco 1978; Eppley et al. 1984; Passow 1991; Crawford and Purdie 1992). In addition to thermal stratification and related conditions (warm temperatures, low turbulence, nutrient starvation), increased proliferation of red-tide assemblages in coastal waters have been recently associated with an increase in the N:Si ratio of nutrients available to natural microplankton populations (Smayda 1990; Watanabe et al. 1995).

Dramatic changes in the biochemical composition of red-tide organisms occur, connected with their diel vertical migration. Carbohydrate synthesis in the surface layers during the photoperiod, and incorporation of nitrogen at the nutricline for protein synthesis during the dark induce diurnal changes in the carbohydrate:protein ratio (Eppley et al. 1968; Cullen et al. 1985). Carbon losses in the dark were observed by Eppley and Sharp (1975), mostly at the expense of polysaccharides (Morris and Skea 1978). Such diel metabolic cycles seem to be coupled to the light-dark cell cycle (Eppley 1981; Morris 1981; Cuhel et al. 1984). The ability of dinoflagellates to migrate vertically seems to be induced by nitrogen starvation in surface waters, as observed in Gyrodinium aureolum (Paasche et al. 1984) and Gonyaulax polyedra (Harrison 1976). On the other hand, the ability for active migration of some chain-forming diatoms (Rhizosolenia mats), induced by changes in buoyancy associated with the carbohydrate:protein ratio, have been recently demonstrated by Richardson and Cullen (1995) and Moore and Villareal (1996). In contrast, diatom migration is not coupled to the diel cell cycle.

Recurrent red-tide events are a serious threat to the success of mussel rafts, which have been intensively cultured in the Rías Baixas (northwest Spain) from the middle of this century. The classical annual cycle of microplankton species in temperate seas was established by Margalef et al. (1955) and Durán et al. (1956) for 
these large coastal embayments, where residual circulation is strongly affected by shelf wind-stress (Blanton et al. 1984). Northerly winds cause upwelling of Eastern North Atlantic Central Water (Fraga 1981) and enhance the estuarine circulation (Prego and Fraga 1992). In contrast, southerly winds generate downwelling and move shelf-surface waters towards the ría. A reversal of this positive circulation pattern occurs during strong downwelling events (Rosón et al. 1997). From May to October, intermittent northerly winds produce a 1 to 2 wk stress/relaxation cycle (Blanton et al. 1987; Alvarez-Salgado et al. 1993) that results in the annual succession from small pioneer diatoms to red-tide species occurring several times during this period (Figueiras and Ríos 1993; Pazos et al. 1995). During upwelling events, diatoms are the dominant taxon (Figueiras and Niell 1987). During the subsequent upwelling relaxation, a subsurface chlorophyll a maximum usually develops, consisting of small diatoms and several dinoflagellates, oligotric ciliates and small flagellates. Eventually, after prolonged periods of non-wind-forced conditions ( $10 \mathrm{~d}$; Alvarez-Salgado et al. 1996), stratification and nutrient depletion in the upper water column is accompanied by the development of red-tide forming species (Pingree et al. 1976; Figueiras and Ríos 1993).

During an in situ $24 \mathrm{~h}$ experiment in the Ría de Vigo, the microplankton population was clearly dominated by diatoms, but an assemblage of red-tide species began to develop. The ability of Ceratium furca, Mesodinium rubrum, Eutreptiella sp., Scrippsiella trochoidea and Dinophysis acuminata for vertical migration has been confirmed in the field (Villarino et al. 1995). Physical and chemical data were monitored during the course of the experiment. Therefore, we were able to record in situ the hydrodynamic and chemical conditions that accompanied pronounced planktonic biochemical changes at the beginning of a succession from diatoms to red-tide species. It must be observed that a period of $24 \mathrm{~h}$ is too short to investigate circadian rhythms (causes, mechanisms, etc.); it only accurately reflects the strong biochemical changes observed during the sampling period. The present study is one 
of the few describing vertical migration in the field; the abundant literature available is mainly based on controlled laboratory experiments. Although diatom dominance is linked to silicate availability (Smayda 1990; Egge and Aksnes 1992), the present paper describes a case where silicate exceeded diatom requirements but the diatoms still declined. The causes for such decline, and the ability of red-tide assemblages to take advantage of favourable environmental conditions are discussed.

\section{Material and methods}

A diel experiment was carried out in the Ría de Vigo at Station $3 b\left(42^{\circ} 14.5^{\prime} \mathrm{N} ; 8^{\circ} 45.8^{\prime}\right.$ W), at 39 m depth (Fig. 1). The station was sampled from 10:50 hrs Greenwich Mean Time (GMT) on 19 September to 11:00 hrs GMT on 20 September 1991 at $2 \mathrm{~h}$ intervals. Samples were drawn from five depths with 5-litre Niskin bottles. Collection depths were determined from salinity, temperature and fluorescence profiles obtained with a CTD (conductivity - temperature - depth) probe Sea Bird Electronics Model 9 and a Sea Tech fluorometer, both attached to a General Oceanics rosette.

\section{Chemical analyses}

Salinity was determined from conductivity measurements (UNESCO 1983), using an AUTOSAL $8400 \mathrm{~A}$ with a precision of \pm 0.003 pss (practical salinity scale: UNESCO 1995). Nutrients were analysed on board by Technicon AAll segmented flowanalysis according to Hansen and Grasshoff (1983), with some small modifications (Mouriño and Fraga 1985; Alvarez-Salgado et al. 1992). The precision is \pm 0.1 $\mu \mathrm{mol} \mathrm{kg}{ }^{-1}$ for nitrate, $\pm 0.02 \mu \mathrm{mol} \mathrm{kg}{ }^{-1}$ for nitrite, $\pm 0.05 \mu \mathrm{mol} \mathrm{kg}{ }^{-1}$ for ammonium and silicate, and $\pm 0.01 \mu \mathrm{mol} \mathrm{kg}{ }^{-1}$ for phosphate. Particulate organic carbon and nitrogen were collected on Whatman GF/F filters in the upper $10 \mathrm{~m}$. The filtration volume was 
$\leq 500 \mathrm{ml}$. Analyses were performed in a PE2400 CHN elemental analyser with a precision of $\pm 0.1 \mu \mathrm{mol} \mathrm{kg}{ }^{-1}$ for carbon and $\pm 0.04 \mu \mathrm{mol} \mathrm{kg}^{-1}$ for nitrogen.

\section{Fluorimetric measurements}

Fluorimetric measurements were made with a 10000 R Turner Designs fluorometer, on water samples dark-adapted at ambient temperature for 20 min (Bates 1985; Falkowski and Kiefer 1985; Kolber et al. 1990). In vivo fluorescence (E) was measured directly, and maximum in vivo fluorescence $(\underline{\mathrm{Fm}})$ was measured after the addition of a saturated solution of 3-(3,4-dichlorophenyl)-1,1-dimethylurea (DCMU). The maximum change in the quantum yield of fluorescence $\left(\Delta \phi_{\mathrm{sat}}=[\mathrm{Fm}-\underline{\mathrm{F}}]: \underline{\mathrm{Fm}}\right)$ is a measurement of the photosynthetic conversion efficiency, which has been suggested to be a diagnostic of nutrient limitation during phytoplankton photosynthesis (Kolber et al. 1990; Falkowski et al. 1991; Geider et al. 1993), independent of irradiance in nutrient-replete conditions. Chlorophyll $\underline{a}$ concentrations were determined by fluorometry of acetone extracts (Yentsch and Menzel 1963).

\section{$\underline{P}-\underline{1}$ curves}

Photosynthesis - irradiance relationships ( $\underline{P} \_\underline{-}$ curves) were studied during the photoperiod. Samples were taken in the upper $10 \mathrm{~m}$ at 10:52, 14:20 and 15:56 hrs GMT on 19 September and at 08:18 and 09:40 hrs GMT on 20 September. Fourteen subsamples from each depth were incubated in $75 \mathrm{ml}$ disposable plastic tissueculture flasks, inoculated with $1.85 \times 10^{5} \mathrm{~Bq}(5 \mu \mathrm{Ci})$ of $\mathrm{Na}_{2}{ }^{14} \mathrm{CO}_{3}$. Incubations were performed in lineal circulating-water incubators for $\sim 2 \mathrm{~h}$. The fronts of the incubators were illuminated by Osram tungsten—halogen lamps (50 W, $12 \mathrm{~V})$. Surface seawater was pumped round the incubators to keep them cool. Irradiance at the surface of each incubation flask was measured with a cosine-sensor, LiCor Li-190SA. The flask opposite to the light source in the lineal incubator was covered with aluminium foil as 
a control (i.e. dark ${ }^{14} \mathrm{C}$ fixation). After incubation, samples were filtered under low vacuum through Whatman GF/F filters (25 $\mathrm{mm}$ diam) and exposed to fuming $\mathrm{HCl}$ for $12 \mathrm{~h}$. The dpm were determined in a Packard liquid scintillation counter, using the external standard method to correct for quenching. As photoinhibition was not observed, the $\underline{P} \_\underline{I}$ data were fitted to the model of Webb et al. (1974).

Photosynthetic active radiation (PAR) profiles were obtained at $2 \mathrm{~m}$ intervals at each $\underline{P}-\underline{I}$ station with a spherical quantum sensor, LiCor Li-193SA, after each CTD cast. PAR in the air at the sea surface $\left(\underline{E}_{0}^{+}\right)$was continuously measured and logged at 20 min intervals with a LiCor Li-190SA. Underwater PAR at $0 \mathrm{~m}$ depth ( $\left.\underline{E}_{0}^{-}\right)$ was calculated by adjusting the PAR profile to the classical equation of light attenuation with depth $\left(\underline{E}=\underline{E}_{0}^{-} \times \mathrm{e}^{-\underline{k}} \times \underline{z}\right)$. The ratio $\underline{E}_{\underline{0}}^{-}: \underline{E}_{0}^{+}$is an empirical measure of light attenuation at the air-sea interface.

Wind stress

The upwelling index ( $\left.\underline{I}_{\mathbf{w}}\right)$, a rough estimate of the water flow upwelled per kilometre of coast, was calculated according to Wooster et al. (1976):

$I_{w}=\frac{\rho_{a} \cdot C \cdot|\vec{V}|}{f \cdot \rho_{w}} \cdot V_{N}$

where $\rho_{\mathrm{a}}=$ density of air $\left(1.22 \mathrm{~kg} \mathrm{~m}^{-3}\right)$ at $15^{\circ} \mathrm{C} ; \underline{\mathrm{C}}=$ empirical drag coefficient (dimensionless), $1.3 \cdot 10^{-3}$ (Hidy 1972); $f=$ Coriolis parameter, $9.946 \cdot 10^{-5} \mathrm{~s}^{-1}$ at Latitude $43^{\circ} ; \rho_{\mathrm{w}}=$ density of seawater $\left(\sim 1025 \mathrm{~kg} \mathrm{~m}^{-3}\right) ;|\overrightarrow{\mathrm{V}}|=$ wind speed; and $\underline{\mathrm{V}}_{\mathrm{N}}=$ northern component of wind speed. Geostrophic winds were calculated from surface pressure charts at $43^{\circ} \mathrm{N}, 11^{\circ} \mathrm{W}$ (Bakun 1973).

\section{Current meters}

Residual currents were obtained at the sampling site from an array consisting of four Aanderra current meters deployed at 9, 19, 29 and $35 \mathrm{~m}$ depth. Data were logged at 
20 min intervals. Tidal and residual currents were predicted from harmonic analysis of each velocity component of the data (Pugh 1987), and the harmonic component was subtracted from each meter record to estimate the residual components.

\section{Results}

Hydrography and residual circulation

Current-meter residual flows along the main axis of the ría showed ingoing currents at 9 and $19 \mathrm{~m}$ depth of 3.2 and 6.3 and $\mathrm{km} \mathrm{d}^{-1}$, respectively (Fig. 2a), whereas outgoing currents of 3.2 and $1.8 \mathrm{~km} \mathrm{~d}^{-1}$ were recorded at 29 and $34 \mathrm{~m}$ depth. The observed net inward-flow must be compensated by an equivalent net outward-flow in the surface layer. The pycnocline (at 3.5 to $4 \mathrm{~m}$ depth) is the boundary between the opposite flows (Pritchard 1969; Prego and Fraga 1992; Rosón et al. 1997).

Three layers were defined according to the velocity field along the main axis of the Ría (Fig. 2b): (1) a surface outgoing-layer (SOL) from the surface to $4 \mathrm{~m}$ depth; (2) an intermediate ingoing-layer (IIL), from 4 to $26 \mathrm{~m}$ depth, displacing at a depthaveraged velocity of $3.5 \mathrm{~km} \mathrm{~d}^{-1}$; (3) a bottom outgoing-layer (BOL), from $26 \mathrm{~m}$ to the bottom, displacing at a depth-averaged velocity of $1.7 \mathrm{~km} \mathrm{~d}^{-1}$.

The velocity in the SOL can be estimated assuming bidimensionality (i.e. currents at Station 3b are representative for the cross-section) and considering the geometry and the average salinity of each layer (Table 1). Average water density, $1000+\gamma\left(\mathrm{S}, \theta, 0\right.$ ), was $\sim 1025 \mathrm{~kg} \mathrm{~m}^{-3}$ (where $\mathrm{S}=$ salinity; $\theta=$ potential temperature; $0=$ atmospheric pressure). The net amount of salt transported into the ría by the IIL was $4.523 \times 10^{12} \mathrm{~g} \mathrm{~d}^{-1}\left(=35.617 \mathrm{~g} \mathrm{~kg}^{-1}\right.$ seawater $\left.\times 1025 \mathrm{~kg} \mathrm{~m}^{-3} \times 35400 \mathrm{~m}^{2} \times 3500 \mathrm{~m} \mathrm{~d}^{-1}\right)$. As the BOL only carried $0.618 \times 10^{12} \mathrm{~g} \mathrm{~d}^{-1}\left(=35.774 \mathrm{~g} \mathrm{~kg}^{-1}\right.$ seawater $\times 1025 \mathrm{~kg} \mathrm{~m}^{-3} \mathrm{x}$ $9910 \mathrm{~m}^{2} \times 1700 \mathrm{~m} \mathrm{~d}^{-1}$ ), the SOL must transport outwards the remaining $3.905 \times 10^{12}$ $\mathrm{g} \mathrm{d}^{-1}$ of salt, assuming that the law of conservation of mass was valid inside the embayment. As the average salinity in the SOL was 35.020 pss $\left(\sim \mathrm{g} \mathrm{kg}^{-1}\right.$ seawater $)$, 
The SOL outflow must be $1259 \mathrm{~m}^{3} \mathrm{~s}^{-1}\left(=3.905 \times 10^{12} \mathrm{~g} \mathrm{~d}^{-1} \div 35.020 \mathrm{~g} \mathrm{~kg}^{-1}\right.$ seawater $\div$ $1025 \mathrm{~kg} \mathrm{~m}^{-3}$ ). Finally, the average velocity of the SOL, $9.9 \mathrm{~km} \mathrm{~d}^{-1}$, was calculated by dividing the flow by the cross-section of the layer $\left(11000 \mathrm{~m}^{2}\right)$.

The net volume of ocean water transported into the ría was $1239 \mathrm{~m}^{3} \mathrm{~s}^{-1}$ $\left(=35400 \mathrm{~m}^{2} \times 3500 \mathrm{~m} \mathrm{~d}^{-1}-9910 \mathrm{~m}^{2} \times 1700 \mathrm{~m} \mathrm{~d}^{-1}\right)$, which means that the contribution of continental runoff to the SOL was only $\sim 20 \mathrm{~m}^{3} \mathrm{~s}^{-1}\left(=1259 \mathrm{~m}^{3} \mathrm{~s}^{-1}-\quad-1239 \mathrm{~m}^{3} \mathrm{~s}^{-1}\right)$, assuming conservation of volume in the ría. This value agrees very well with the average flow of $\sim 15 \mathrm{~m}^{3} \mathrm{~s}^{-1}$ from 15 to 20 September, obtained by an independent method based on rainfall and retention in the drainage basin (Ríos et al. 1992). The net ingoing volume of ocean-water upwells throughout the surface area of the ría from the study site to the river mouth $\left(56.4 \times 10^{6} \mathrm{~m}^{2}\right)$ and moves back through the surface layer to the study site. Consequently, water from the IIL entered the SOL at an average upward velocity of $1.9 \mathrm{~m} \mathrm{~d}^{-1}\left(=1239 \mathrm{~m}^{3} \mathrm{~s}^{-1} \div 56.4 \times 10^{6} \mathrm{~m}^{2}\right)$.

Despite the strong flows recorded at the sampling site, there were no significant changes in water masses throughout the diel experiment, as confirmed by the composite temperature — salinity diagram for the 13 casts (Fig. 3). This indicates steady-state conditions during the sampling period. The hydrographic structure resulted from the mixing of two end-members: (1) surface water with a salinity of $34.81 \pm 0.09$ pss (average \pm SD) and a temperature of $21.5 \pm 0.5^{\circ} \mathrm{C}$; and (2) Eastern North Atlantic Central Water (ENACW), which upwelled over the shelf and entered the ría, driven by moderate northerly winds on 18 September (Fig. 4). The thermohaline properties of source ENACW from an oceanic reference station off the Ría de Vigo (occupied on 16 September) fit to the straight line:

$S=35.738+0.147 \times(\theta-11)$

$\left(\underline{r^{2}}=0.996 \quad \underline{n}=14\right)$

The ENACW end-member into the ría was characterised by 35.95 pss and $12.44{ }^{\circ} \mathrm{C}$ (square on ENACW line in Fig. 3). An uplift of the isopycnals was apparent in the 
surface layer at 10:00 and 22:00 hrs GMT on 19 September, and at 11:00 hrs GMT on 20 September, coinciding with the maximum tidal velocity during rising tides (Fig. $5 a)$.

Net nutrient uptake and mineralization

Nutrient input to the SOL by continental runoff can be roughly estimated; we took a net flow of $17.5 \mathrm{~m}^{3} \mathrm{~s}^{-1}$ (average between our two independent estimations). Continental input to the rías deliver from 20 to $40 \mu \underline{\mathrm{M}}$ of nitrate and $105 \mu \underline{\mathrm{M}}$ of silicate (Pérez et al. 1992). Consequently, nutrients transported by continental runoff were 0.54-1.07 mmol N m $\mathrm{m}^{-2}$ and $2.81 \mathrm{mmol} \mathrm{Si} \mathrm{m}^{-2} \mathrm{~d}^{-1}\left(=105 \mathrm{mmol} \mathrm{m}^{-3} \times 17.5 \mathrm{~m}^{3} \mathrm{~s}^{-1} \div\right.$ $\left.56.4 \times 10^{6} \mathrm{~m}^{2}\right)$.

Inorganic nitrogen $\left(\mathrm{NO}_{3}{ }^{-}+\mathrm{NO}_{2}{ }^{-}+\mathrm{NH}_{4}{ }^{+}\right)$concentration was $<0.3 \mu \mathrm{mol} \mathrm{kg}{ }^{-1}$ in the SOL; it increased rapidly throughout the subsurface layers (Fig. 5b, c, d). Nitrate concentration in source-ENACW off the Ría de Vigo correlated well with temperature, following the linear relationship:

$\mathrm{NO}_{3}{ }^{-}=45.8( \pm 0.9)-3.1( \pm 0.4) \times \theta$

$\left(\underline{r^{2}}=0.90 \quad \underline{n}=8\right)$

$\theta$ and nitrate in source-ENACW ranged from 11.5 to $13.8^{\circ} \mathrm{C}$ and 3 to $12 \mu \mathrm{mol}$ $\mathrm{kg}^{-1}$, respectively. Nitrite and ammonium concentration was $<0.3 \mu \mathrm{mol} \mathrm{kg}{ }^{-1}$. Nitrate concentration in the ENACW end-member $\left(\theta=12.44{ }^{\circ} \mathrm{C}\right)$ would be $7.2 \mu \mathrm{mol} \mathrm{kg}{ }^{-1}$ if only advection and mixing of this ocean water-body occurred. However, average nitrate concentration in the $\mathrm{BOL}$, with $\sim 85 \%$ of the ENACW end-member $[=(35.774$ $34.81) \div(35.95-34.81) \times 100]$, was $10.5 \pm 1.1 \mu \mathrm{mol} \mathrm{kg}^{-1}$ and high levels of nitrite and ammonium were also recorded, $1.1 \pm 0.1$ and $3.5 \pm 0.9 \quad \mu m o l k^{-1}$, respectively. This was a consequence of the well-documented nutrient enrichment of upwelled ENACW by mineralization processes over the shelf and in the rías (Fraga 1981; Alvarez-Salgado et al. 1993; 1997). About 60\% [= (15.1 - $0.85 \times 7.2) \div 15.1 \times$ 
100] of the inorganic nitrogen in the $\mathrm{BOL}$ originated from mineralization of organic matter. Nutrient enrichment by mineralization was also important in the IIL, as evidenced by the high ammonium concentrations observed throughout this layer (3.2 $\pm 1.3 \mu \mathrm{mol} \mathrm{kg}^{-1}$ ). Phosphate concentration (not shown) in the SOL was high, $0.23 \pm$ $0.09 \mu \mathrm{mol} \mathrm{kg}{ }^{-1}$. Paralleling nitrate, phosphate enrichment due to mineralization was observed in the IIL and BOL.

Silicate in the SOL was variable, with values of $>3 \mu \mathrm{mol} \mathrm{kg}{ }^{-1}$ coinciding with the uplift of isopycnals during flood tides (Fig. 5e). The average concentration was $2.9 \pm 1.3 \mu \mathrm{mol} \mathrm{kg}{ }^{-1}$, or $11.6 \mathrm{mmol} \mathrm{m}^{-2}$. In the lower layers, silicate enrichment by dissolution of diatom frustules occurred, coupled with mineralization of organic matter. Silicate concentration in source-ENACW can be calculated from the linear relationship with temperature in the oceanic reference station:

$\mathrm{Si}(\mathrm{OH})_{4}=13.9( \pm 0.4)-0.9( \pm 0.3) \times \theta$

$\left(\underline{r^{2}}=0.69 \quad \underline{n}=8\right)$

In source-ENACW, silicate ranged from 2.0 to $3.5 \mu \mathrm{mol} \mathrm{kg}^{-1}$; therefore, at $12.44{ }^{\circ} \mathrm{C}$, only $2.7 \mu \mathrm{mol} \mathrm{kg}^{-1}$ were expected. However, as much as $13.6 \pm 1.0 \mu \mathrm{mol}$ $\mathrm{kg}^{-1}$ were observed in the BOL, i.e. $\sim 80 \%$ of silicate must have originated from opal dissolution. This important enrichment of silica compared to nitrogen has already been described for this area, and is a common feature in upwelling systems (AlvarezSalgado et al. 1997).

Dissolved oxygen (Fig. 5f) exhibited a strong gradient throughout the water column, being oversaturated in the SOL, with extremely high values $>370 \mu \mathrm{mol} \mathrm{kg}^{-1}$ (180 \% of saturation) at the surface. Concomitant with the mineralization pattern, oxygen dramatically decreased towards the bottom, where concentrations as low as $110 \mu \mathrm{mol} \mathrm{kg}{ }^{-1}$ (45 \% of saturation) were measured. The effect of the tidal cycle was observed in the lower layer. Maximum uplift of the $120 \mu \mathrm{mol} \mathrm{kg}{ }^{-1}$ isoline coincided with low tides, as water from the inner ría, where mineralization is more intense, 
reached the sampling site. A relative increase in silicate (Fig. 5e) occurred after the low tides.

In accordance with the classical circulation pattern for partially-mixed estuaries, net transport of mineralized nutrients from the IIL to the SOL took place by upward compensation flow. Nutrient concentrations at 4 to $5 \mathrm{~m}$ depth (the boundary between the two layers) were $2.22 \pm 0.41 \mu \mathrm{mol} \mathrm{kg}{ }^{-1}$ of nitrate, $0.38 \pm 0.04 \mu \mathrm{mol} \mathrm{kg}{ }^{-1}$ of nitrite, $0.85 \pm 0.80 \mu \mathrm{mol} \mathrm{kg}{ }^{-1}$ of ammonium and $6.82 \pm 0.62 \mu \mathrm{mol} \mathrm{kg}^{-1}$ of silicate, averaged over the whole in situ diel experiment. Consequently, $6.72 \mathrm{mmol} \mathrm{N} \mathrm{m} \mathrm{d}^{-2}$ ${ }^{1}\left(=3.46 \mu \mathrm{mol} \mathrm{kg}{ }^{-1} \times 1025 \mathrm{~kg} \mathrm{~m}^{-3} \times 1.9 \mathrm{~m} \mathrm{~d}^{-1}\right)$ and $13.3 \mathrm{mmol} \mathrm{Si} \mathrm{m}{ }^{-2} \mathrm{~d}^{-1}$ were transported from the IIL to the SOL. The contribution of vertical mixing $\left(\underline{K_{z}}\right)$ to nutrient transport was negligible across the pronounced pycnocline. Worthy of note is the high silicate concentration at 4 to $5 \mathrm{~m}$ depth, where the contribution of the ENACW end-member was $\sim 50 \%$. The $\mathrm{N}$ :Si molar ratio of transported nutrients was 0.5 . Continental runoff comprised only 7 to $14 \%$ of the total inorganic nitrogen and $17 \%$ of the total silicate input to the SOL.

Net community production (NCP) in the SOL is the same as oceanic plus continental inputs (7.26 to $7.79 \mathrm{mmol} \mathrm{N} \mathrm{m}^{-2} \mathrm{~d}^{-1}$ or 102 to $109 \mathrm{mg} \mathrm{N} \mathrm{m}^{-2} \mathrm{~d}^{-1}$ ) since N- nutrient was absent. As the SOL was $4 \mathrm{~m}$ deep and the average upward flow was 1.9 $\mathrm{m} \mathrm{d}^{-1}$, this calculation assumes steady-state conditions over $\sim 2 \mathrm{~d}$. The net uptake of silicate was also calculated by subtracting the daily average concentration in the SOL to the total net input; a value of $4.49 \mathrm{mmol} \mathrm{Si} \mathrm{m}^{-2} \mathrm{~d}^{-1}$ was obtained. The net $\mathrm{N}: \mathrm{Si}$ molar uptake ratio was 1.7.

Diurnal pattern in C:N ratio and primary production High concentrations of particulate organic nitrogen (PON) were observed in the SOL, with the maximum at the pycnocline ( 3.5 to $4 \mathrm{~m}$ depth), except at the beginning and at the end of the diel experiment ( 11 h GMT on 19 and 20 September) when the maximum rose to the surface (Fig. 6a). The PON distribution resembled that of 
chlorophyll (Fig. 6e), which was demonstrated to be composed of two main microplankton assemblages during parallel sampling (Villarino et al. 1995): (1) a diatom assemblage consisting of elongated diatoms (Thalassionema nitzschoides, Asterionella japonica and unidentified pennate species) and centric diatoms (Thalassiosira nana), which constituted $>60 \%$ of the total cell numbers in most of the samples, and was the responsible for the chlorophyll maximum observed at the pycnocline; (2) a community of medium and large dinoflagellates and ciliates, which included a red-tide assemblage of five species capable of vertical migration, following a marked diurnal pattern (Ceratium furca, Scrippsiella trochoidea, Dinophysis acuminata, Mesodimium rubrum and Eutreptiella sp.) (present Fig. 6d). Despite strong water circulation (see present Fig. 2), Villarino et al. also concluded from both hydrodynamic calculations (Richardson number) and principal component analyses that the observed species distributions during the diel experiment were due neither to different phytoplankton communities associated with phytoplankton patches, nor to horizontal dispersion or depth variation in cell numbers. In the present study, $\Delta \underline{\phi}_{\text {sat }}$ (Fig. 6f) was also closely related to chlorophyll distribution, with maximum values of $>0.5$ at the pycnocline and as much as $>0.6$ in surface waters at $\sim 11 \mathrm{hrs}$ GMT on 19 and 20 September, i.e. when red-tide species were concentrated in the surface (Fig. $6 d)$.

The C:N molar ratio of particulate organic matter, displayed a diurnal pattern (Fig. 6b). At the depth of the chlorophyll maximum, higher $\mathrm{C}: \mathrm{N}$ ratios were observed during the photoperiod, being $>9$ at $15: 00 \mathrm{hrs}$ GMT. C:N ratios dramatically decreased during the dark, down to values of $<6$ at 5:00 hrs GMT. Superimposed over this daily periodicity was a vertical gradient, with $\mathrm{C}: \mathrm{N}$ ratios decreasing with increasing depth in both light and dark. The combination of the diurnal and vertical patterns resulted in the distribution of the $\mathrm{C}: \mathrm{N}$ ratio observed.

Active vertical migration of some diatom species by means of pronounced changes in buoyancy (related to the carbohydrate:protein ratio) have recently been 
observed (Richardson and Cullen 1995; Moore and Villarreal 1996). In the present study, the time-course of diatom numbers (as percentage of total diatoms in the water column) did not indicate active buoyancy (Fig 6c).

Short $\underline{P}-\underline{l}$ incubations $(\sim 2 \mathrm{~h})$ do not allow the respiration of the inoculated ${ }^{14} \mathrm{C}$ to be taken into account and gross primary production (GPP) at depth $\underline{z}$ can be estimated by the equation:

$$
\text { GPP }=\text { chl } \underline{a} \times \underline{P}_{\max } \times\left\{1-\exp \left[-\underline{E}_{\underline{O}}{ }^{-} \times \exp (-\underline{\mathrm{k}} \times \underline{\mathrm{z}}) / \underline{\underline{I}}_{\underline{k}}\right]\right\},
$$

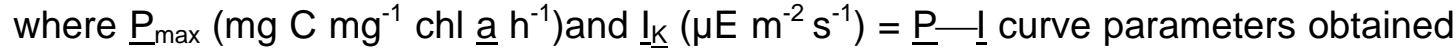
by fitting the experimental data to the classical inverse exponential equation (Webb

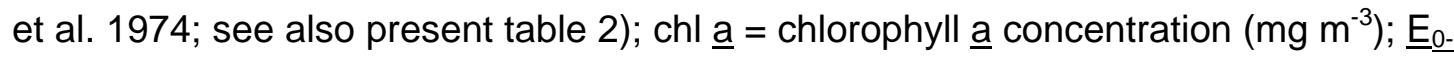
and $\underline{k}=$ underwater surface irradiance at surface $\left(\mu \mathrm{E} \mathrm{m} \mathrm{m}^{-2}\right)$ and coefficient of light attenuation with depth $\left(\mathrm{m}^{-1}\right)$, respectively.

Depth-integrated GPP in the SOL was calculated for every cast within the photoperiod by integrating discrete primary production estimated metre by metre with Eq. (5). Chlorophyll a was estimated from the fluorescence profiles obtained with the Sea Tech fluorometer attached to the CTD probe, and the $\underline{P}-\underline{I}$ curve parameters were interpolated for intermediate depths. Daily-integrated GPP was estimated using the continuous overwater PAR record $\left(\underline{\mathrm{E}}_{0}{ }^{+}\right)$from the LiCor Li-190SA sensor and the empirical $\underline{E}_{0}^{-:} \underline{E}_{0}^{+}$ratio. Values of $1525 \mathrm{mg} \mathrm{C} \mathrm{m}^{-2} \mathrm{~d}^{-1}$ and 370 $\mathrm{mg} \mathrm{C} \mathrm{m}^{-2} \mathrm{~d}^{-1}$ were obtained for SOL and IIL, respectively.

\section{Discussion and conclusions}

The N:Si molar ratio in source-ENACW at $12.44{ }^{\circ} \mathrm{C}$ was 2.7 . As the N:Si composition ratios of marine diatom are $\sim 1$ (Brzezinski 1985), the observed nutrient ratio would be likely to limit diatom growth by silicon starvation (Howarth 1988; Dugdale et al. 1995), and would thus lead to the recurrent dominance of red-tide species (Officer and Ryther, 1980; Levasseur and Therriault 1987). However, nutrient limitation can 
be reversed in upwelling areas by preferential silicate enrichment during mineralization processes (Alvarez-Salgado et al. 1997). The Ría de Vigo is a conspicuous example of such reversal. The N:Si ratio in the BOL was decreased to 1.1 by cumulative mineralization in source-ENACW over the shelf and into the ría. Below the pycnocline, where rapid in situ mineralization is usually observed (Holligan et al. 1984; Figueiras and Ríos 1993), the N:Si ratio was as low as 0.5. Dissolution of sinking and deposited diatom frustules, selectively concentrated in the lower layers are probable reasons for the low ratios observed (Dugdale et al. 1995; Nelson et al. 1995).

The $16.1 \mathrm{mmol} \mathrm{Si} \mathrm{m} \mathrm{m}^{-2} \mathrm{~d}^{-1}$ supplied to the SOL would lead to a daily increase of

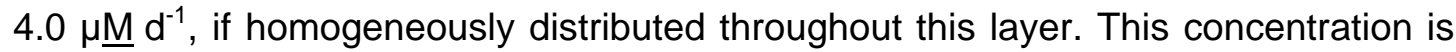
double the threshold of $\sim 2 \mu \underline{M}$ necessary for the inherently high growth rate of diatoms at non-limiting silicate concentrations (Egge and Asknes 1992). Even the actual silicate concentration in the SOL, $2.9 \mu \underline{\mathrm{M}}$, exceeded this threshold; therefore, silica was not the element limiting diatom growth during the diel experiment. As phosphate concentration in the SOL was high $\left(>0.2 \mu \mathrm{mol} \mathrm{kg}{ }^{-1}\right)$, nitrogen would seem to be the limiting nutrient. The net $\mathrm{N}: \mathrm{Si}$ molar uptake ratio (1.7) was 3.4 times the source ratio, and was higher than that expected for growing diatom populations (Brzezinski 1985; Levasseur and Therriault 1987), suggesting that the prevailing diatom assemblage was beginning to decline.

Moderate wind-driven upwelling on 18 September, with an upwelling index of $<750 \mathrm{~m}^{3} \mathrm{~s}^{-1} \mathrm{~km}^{-1}$ coast (Rosón et al. 1997), introduced both mineralized and new nutrients from the ocean to the SOL. The amount of nutrients entering from the IIL was more than five times that supplied by continental runoff; this is usual in the study area at this time of year (Prego 1992; Ríos et al. 1992). Warm watertemperature, high stratification, low turbulence, nutrient enrichment from moderate upwelling and the presence of a shallow mixed layer all combine to provide optimal 
conditions for the development of red-tide species (Cullen et al. 1982; Chang and Carpenter 1985; Thomas and Gibson, 1990; Berdalet and Estrada, 1993).

Net community production in the SOL, estimated from current velocity and nitrogen distribution, was $105 \mathrm{mg} \mathrm{N} \mathrm{m}^{-2} \mathrm{~d}^{-1}$ or $630 \mathrm{mg} \mathrm{C} \mathrm{m}^{-2} \mathrm{~d}^{-1}$, based on a C:N molar uptake ratio of 7 (i.e the average molar ratio of particulate organic matter during the diel experiment). A $\Delta \mathrm{chl} \underline{\mathrm{a}}: \Delta \mathrm{N}$ ratio of $-1 \mathrm{mg} \mathrm{chl} \underline{\mathrm{a}}: \mathrm{mmol} \mathrm{N}$, is typical for phytoplankton in exponential growth (Antia et al. 1963; Eppley et al. 1971; Malone et al. 1983). Using this ratio, the maximum expected net chlorophyll production in the SOL would be $\sim 7.5 \mathrm{mg} \mathrm{m}^{-2} \mathrm{~d}^{-1}$, an amount that probably could not compensate losses by diatom sedimentation and grazing pressure. The declining diatom assemblage concentrated around the pycnocline -the boundary between the opposite-flowing SOL and IIL (Fig. 2). As horizontal motion is largely limited in the pycnocline (Pritchard 1969; Rosón et al. 1997), diatoms could not be transported outwards by the SOL and therefore were sedimented into the ría. In contrast, the ability of red-tide organisms to swim actively and the limited predation by zooplankton (Fielder 1982; Ives 1987) and mussels (Bricelj et al. 1993; Alvarez-Salgado et al. 1996) may allow unhindered development of the red-tide assemblage.

The ratio of net to gross production, which is comparable to Eppley and Peterson's (1979) ratio of new to total production (f-ratio; Platt et al. 1989; Quiñones and Platt 1991), was 0.41 . While NCP was limited by the reduced N-nutrient supply from the IIL, GPP was clearly light-limited, since the $\underline{I}_{\underline{k}}$ was always higher than the PAR (Table 2). Consequently, the high $f$-ratio observed, which is characteristic of upwelling conditions (Eppley 1989; Chisholm 1992; Dugdale and Wilkerson 1992), arose from the a combination of light limitation of carbon production, and nutrient limitation of nitrogen production. Had the PAR been higher than $\underline{\underline{k}}$ during the photoperiod, i.e. GPP $=$ chl $\underline{a} \times P_{\max }$, then daily-integrated GPP would have been $4096 \mathrm{mg} \mathrm{C} \mathrm{m}^{-2} \mathrm{~d}^{-1}$, and the $\mathrm{f}$-ratio would decreased to 0.15 . Rapid development of red-tide assemblages usually occurs at high ammonium concentrations or very low $f$ - 
ratios (Fraga et al. 1988; Prego 1992; Le Core and L'Helguen 1993; Ríos et al. 1995).

Within this hydrodynamic and chemical framework, the conspicuous diurnal pattern in the $\mathrm{C}: \mathrm{N}$ ratio (Fig. $6 \mathrm{~b}$ ) was mostly due to changes in the biochemical composition of the diatom assemblage. Diatoms are able to incorporate nitrate (Balch 1987) and ammonium (Balch 1985) and to synthesise proteins (Morris and Skea 1978; Barlow 1984a; Cuhel et al. 1984) both day and night, and proteins can make up $90 \%$ of the total cellular nitrogen (Laws 1991). Although assimilation of nitrogen is stimulated by light, day/night differences are less pronounced under conditions of nitrogen limitation (Vincent 1992). Continuous assimilation of nitrogen during both the photoperiod and the dark is supported by the low levels of inorganic nitrogen $\left(<0.3 \mu \mathrm{mol} \mathrm{kg}^{-1}\right)$ observed throughout the diel experiment. Massive production of carbohydrates during the photoperiod is necessary to cover the carbon and energetic requirements for maintenance of diatom cells and for nitrate uptake and reduction and protein synthesis in the dark (Laws and Wong 1978; Barlow 1984a; Barlow 1984b; Flynn 1990; Martin-Jézéquel 1992; Vincent 1992). Consequently, C: $\mathrm{N}$ ratios of a diatom population may exhibit the diurnal pattern observed during the present experiment, increasing during the photoperiod by means of carbohydrates synthesis enhanced by light intensity (Morris 1981; Martin-Jézéquel 1992), and decreasing during the dark, when only protein synthesis can occur. The cumulative effect of the predominant net carbohydrate-synthesis is clearly evidenced by the high oversaturation of dissolved oxygen in the nitrogen-depleted SOL (Fig. 5f), with subsequent losses to the atmosphere.

Dinoflagellates that are able to swim (Villarino et al. 1995) synthesised carbohydrates during the day in the surface layer, and proteins during the night at the pycnocline (Eppley et al. 1968; Dorch and Maske 1982; Yamochi and Abe 1984; Cullen et al. 1985; Hamma et al. 1988; Fraga et al. 1992). The cytoplasm density of dinoflagellates is usually higher than that of diatoms (Hitchcock 1982). In our study, 
the difference may have been enhanced by the decrease in the cellular content of the diatoms as growth slowed (Moal et al. 1987). The reduced cell number of the redtide assemblage (Villarino et al. 1995) only slightly enhanced the diurnal pattern observed (Fig. 6f), by increasing the $\mathrm{C}: \mathrm{N}$ ratio at the surface during the photoperiod and decreasing the ratio at the pycnocline during the dark. Growth rates of dinoflagellates (usually $<0.5 \mathrm{~d}^{-1}$ ) are substantially lower than those of other taxa (Tang 1996 and references therein). In the case of a massive red-tide of Gymnodinium catenatum in the Ría de Vigo, biomass duplicated after two diel cycles (48 h) because of limited carbohydrate-storage capacity of the cells, when the pycnocline was at $10 \mathrm{~m}$ depth (Fraga et al. 1992). In our study, where the pycnocline was at only $4 \mathrm{~m}$ depth, the energy required by dinoflagellates for active swimming was probably far less than that observed by Fraga et al. (1992). As our experiment covered only $24 \mathrm{~h}$, cell accumulation was not observed. However progressive concentration of red-tide species in the highly stratified SOL could occur after several diel vertical migration cycles. Increasing cell numbers during the photoperiod in the surface layer would raise the coefficient of light extinction ( $\underline{k}$ ) with depth and would progressively reduce the availability of PAR for the diatom assemblage at the pycnocline. Only 20 to $30 \%$ and 45 to $50 \%$ of $\underline{E}_{0}^{-}$reached the pycnocline during the photoperiod on 19 and 20 September, respectively. Consequently, the diatoms may collapse when light-limited carbohydrate production during the photoperiod is not able to meet all of their dark cycle energy requirements. 
Acknowledgements The authors wish to thank all the participants in the diel experiment from the Instituto de Investigacións Mariñas for their unconditional support, and colleagues from the Dunstaffnage Marine Laboratory for instrument and mooring development and analysis of the buoy data. We are very grateful to the captain and crew of the R.V. "Explorador", for their continuous assistance during sampling. We also thank Dr. R. Barlow and three anonymous reviewers for their valuable comments and criticisms. Support for this work came from the EU project Contract No. MAST-CT90-0017 "Control of Phytoplankton Dominance". A Fellowship from the Spanish Ministerio de Educación y Ciencia enabled M.-L.V. to carry out her Ph.D. thesis as part of this project. 
Literature cited

Antia NJ, McAllister CD, Parsons TR, Stephens K, Strickland JDH (1963) Further measurements of primary production using a large-volume plastic sphere. Limnol Oceanog 8:166-183

Alvarez-Salgado XA, Pérez FF, Fraga F (1992) Determination of nutrient salts by automatic methods both in seawater and brackish water: the phosphate blank. Mar Chem 39: 311-319

Alvarez-Salgado XA, Rosón G, Pérez FF Pazos Y (1993) Hydrographic variability off the Rías Baixas (NW Spain) during the upwelling season. J Geophys Res 98(C8): 14447-14455

Alvarez-Salgado XA, Rosón G, Pérez FF, Figueiras FG, Pazos Y (1996). Nitrogen cycling in an estuarine upwelling system, the Ría de Arousa (NW Spain). I. Short-time-scale patterns of hydrodynamic and biogeochemical circulation. Mar Ecol Prog Ser 135:259-273

Alvarez-Salgado XA, Castro CG, Pérez FF, Fraga F (in press) Nutrient mineralization patters in shelf water of the Iberian Upwelling. Cont Self Res

Bakun A (1973) Coastal upwelling indices, west coast of North America 1946-1971. NOAA technical report, NMFSSSRF-671

Balch WM (1985) Lack of an effect of light on methylamine uptake by phytoplankton. Limnol Oceanogr 30:665-673

Balch WN (1987) Studies of nitrate transport by marine phytoplankton using $\quad{ }^{36} \mathrm{Cl}-$ $\mathrm{ClO}_{3}{ }^{-}$as a transport analogue. I. Physiological findings. J Phycol 23:107-118

Barlow RG (1984a) Time-series uptake of carbon into photosynthetic product of Benguela phytoplankton populations. J Plankton Res 6:435-442

Barlow RG (1984b) Dynamics of the decline of a phytoplankton bloom after an upwelling event. Mar Ecol Prog Ser 16:121-126

Bates SS (1985) Sample preconditioning for measurement of fluorescence induction of Chlorophyll a in marine phytoplankton. J Plankton Res 7:703-714 
Berdalet E, Estrada M (1993) Effects of turbulence on several dinoflagellate species.

In: Smayda TJ, Shimizu Y (eds) Toxic Marine Phytoplankton. Elsevier, New York, pp 737-740

Blanton JO, Atkinson LP, Castillejo FF, Lavín A (1984) Coastal upwelling off the Rías Bajas, Galicia, Northwest Spain, I: Hydrographic Studies. Rapports et ProcesVerbeaux des Reunions Conseil International pour l'Exploration de la mer 183: $79-90$

Blanton JO, Tenore KR, Castillejo FF, Atkinson LP, Schwing FB, Lavín A (1987) The relationship of upwelling to mussel production in the Rías on the western coast of Spain. J Mar Res 45: 497-511

Blasco D (1978) Observations on the diel migration of marine dinoflagellates off the Baja California coast. Mar Biol 46: 41-47

Bricelij VM, Greene M, Cembella AD (1993) Growth of the blue mussel Mytilus edulis on toxic Alexandrium fundyense and effects of gut passage on dinoflagellate cells. In: Smayda TJ, Shimizu Y (eds) Toxic phytoplankton blooms in the sea. Elsevier, Amsterdam, pp 371-376

Brzezinski, MA (1985) The Si:C:N ratio of marine diatoms: interspecific variability and the effect of some environmental variables. J Phycol 21:347-357

Chang J, Carpenter EJ (1985) Blooms of the dinoflagellate Gyrodinium aureolum in a Long Island estuary: box model analysis of bloom maintenance. Mar Biol 89:8393

Chisholm SW (1992) Phytoplankton size. In: Falkowsky PG, Woodhead AD (eds) Primary productivity and biogeochemical cycles in the sea. Plenum, New York, pp 213-238

Crawford DW, Purdie DA (1992) Evidence for avoidance of flushing from an estuary by a planktonic, phototrophic ciliate. Mar Ecol Prog Ser 79: 259-265

Cuhel RL, Ortner RB, Lean DRS (1984) Night synthesis of protein by algae. Limnol Oceanogr 29:731-744 
Cullen JJ, Horrigan SG, Huntley ME, Reid FMH (1982) Yellow water in La Jolla Bay, California, July 1980. I. A bloom of the dinoflagellate Gymnodinium flavum Kofoid and Swezy. J Exp Mar Biol Ecol 63:67-80

Cullen JJ, Mingyuan Zhu, Davis RF, Pierson DG (1985) Vertical migration, carbohydrate synthesis and nocturnal nitrate uptake during growth of Heterocapsa niei in a laboratory water column. In: Anderson DM, White AW, Baden DG (eds) Toxic dinoflagellates. Elsevier, New York, pp 189-194

Dorch Q, Maske H (1982) Dark uptake of nitrate and nitrate reductase activity of a red tide population off Peru. Mar Ecol Prog Ser 9:299-303

Dugdale RC, Wilkerson FP (1992) Nutrient limitation of new production in the sea. In: Falkowsky PG, Woodhead AD (eds) Primary productivity and biogeochemical cycles in the sea. Plenum, New York, pp 107-122

Dugdale RC, Wilkerson FP, Minas HJ (1995) The role of a silicate pump in driving new production. Deep-Sea Res I 42:697-719

Durán M, Sáiz F, López-Benito M, Margalef R (1956) El fitoplancton de la Ría de Vigo, de abril de 1954 a junio de 1955. Investigación pesq. 4: 67-95

Egge JK, Askens DL (1992) Silicate as regulating nutrient in phytoplankton competition. Mar Ecol Prog Ser 83:281-289

Eppley RW (1981) Relations between nutrient assimilation and growth in phytoplankton with a brief review of estimates of growth rate in the ocean. In Platt T (Ed), Physiological Bases of Phytoplankton Ecology. Can Bull Fish Aquat Sci 210: 251-263

Eppley RW (1989) New production: history, methods, problems. In: Berger WH, Smetacek VS, Wefer G (eds) Productivity of the ocean. Present and past. Wiley, Chichester, pp 85-97

Eppley RW, Carlucci AF, Holm-Hansen O, Kiefer D, McCarthy JJ, Venrik E, Williams PM (1971) Phytoplankton growth and composition in shipboard cultures supplied 
with nitrate, ammonium, or urea as a nitrogen source. Limnol Oceanog 16:741751.

Eppley RW, Holm-Hansen O, Strickland DH (1968) Some observations on the vertical migration of dinoflagellates. J Phycol 4:333-340

Eppley RW, Peterson BJ (1979) Particulate organic matter flux and planktonic new production in the deep ocean. Nature, Lond 282:677-680

Eppley RW, Reid FMH, Cullen JJ, Winant CD, Stewart E (1984) Subsurface patch of a dinoflagellate (Ceratium tripos) off Southern California: patch length, growth rate, associated vertically migrating species. Mar Biol 80: 207-214

Eppley RW, Sharp JH (1975) Photosynthetic measurements in the Central North Pacific: the dark loss of carbon in 24h incubation. Limnol Oceanogr 20:981-987

Falkowski P, Kiefer DA (1985) Chlorophyll a fluorescence in phytoplankton: relationship to photosynthesis and biomass. J Plankton Res 7:715-731

Falkowski P.G., D. Ziemann, Z. Kolber and P.K. Bienfang (1991). Role of eddy pumping in enhancing primary production in the ocean. Nature 352: 55-58

Fielder PC (1982) Zooplankton avoidance and reduced grazing response to Gymnodinium splendens (Dynophyceae). Limnol Oceanogr 27: 961-965

Figueiras FG, Niell FX (1987) Composición del fitoplancton en la Ría de Pontevedra (NO de España). Invest pesq 51: 371-409

Figueiras FG, Ríos AF (1993) Phytoplankton succession, red tides and hydrographic regime in the Rías Bajas of Galicia. In: Smayda TJ, Shimizu Y (eds) Toxic Marine Phytoplankton. Elsevier, New York, pp 239-244

Flynn KJ (1990) The determination of nitrogen status in microalgae. Mar Ecol Prog Ser 61:297-307

Fraga F (1981) Upwelling off the Galician Coast, Northwest Spain. In: Richards FA (ed) Coastal Upwelling. American Geophysical Union, Washington, pp 176-182 
Fraga F, Pérez FF, Figueiras FG, Ríos AF (1992) Stoichiometric variations of N, P, $\mathrm{C}$, and $\mathrm{O}_{2}$ during a Gymnodinium catenatum red tide and their interpretation. Mar Ecol Prog Ser 87:123-134

Fraga S, Anderson DM, Bravo I, Reguera B, Steidinger KA, Yentsch CM (1988) Influence of upwelling relaxation on dinoflagellates and shellfish toxicity in Ría de Vigo, Spain. Estuar Coastal Shelf Sci 27:349-361

Geider, R.J., R.M. Greeene, Z. Kolber, H.L. Maclntyre and P.G. Falkowski (1993). Fluorescence assessment of the maximum quantum efficiency of photosynthesis in the western North Atlantic. Deep-Sea Res. I. 40: 1205-1224

Hamma T, Matsunaga H, Handa N, Takahashi M (1988) Day-night changes in production of carbohydrate and protein by natural populations from lake Biwa, Japan. J Plankton Res 10:941-955

Hansen HP, Grasshoff K (1983) Automated chemical analysis. In: Grasshoff K, Ehrhardt M, Kermling K (eds) Methods of seawater analysis. $2^{\text {nd }}$ Edition. Verlag Chemie, Wheinheim, pp 347-395

Harrison WG (1976) Nitrate metabolism of a red tide dinoflagellate Gonyaulax polyedra Stein. J Exp Mar Biol Ecol 21: 199-209

Hasle GR (1950) Phototactic vertical migration in marine dinoflagellates. Oikos $2: 162-176$

Hidy GM (1972) A view of recent air-sea interaction research. Bull Am Meteorol Soc 53:1083-1102

Hitchcok GL (1982) Comparative study of the size-dependent organic composition of marine diatoms and dinoflagellates. J Plankton Res 4:363-377

Holligan PM, Balch WM, Yentsch CM (1984) The significance of subsurface chlorophyll, nitrite and ammonium maxima in relation to nitrogen for phytoplankton growth in stratified waters of the Gulf of Maine. J Mar Res 42:1051-1073 
Howarth RW (1988) Nutrient limitation of net primary production in marine ecosystems. Annual Review of Ecological Systems 19: 89-100

Ives, JD (1987) Possible mechanism underlying copepod grazing to levels of toxicity in red tide dinoflagellate. J Exp Mar Biol Ecol 112: 131-145

Kolber Z, Wyman KD, Falkowsky PG (1990) Natural variability in photosynthetic energy conversion efficiency: a field study in the gulf of Maine. Limnol Oceanogr $35: 72-79$

Laws EA (1991) Photosynthetic quotients, new production and net community production in the open ocean. Deep-Sea Res 38:143-167

Laws EA, Wong DCL (1978) Studies of carbon and nitrogen metabolism of three marine phytoplankton species in nitrate-limited continuous culture. J Phycol $14: 406-416$

Le Core P, L'Helguen S (1993) Nitrogen source for uptake by Gyrodinium cf. aureolum in a tidal front. Limnol Oceanogr 38:446-451

Levasseur ME, Therriault J-C (1987) Phytoplankton biomass and nutrient dynamics in a tidally induced upwelling: the role of the $\mathrm{NO}_{3}: \mathrm{SiO}_{4}$ ratio. Mar Ecol Prog Ser 39:87-97

Malone TC, Hopkins TS, Falkowski PG, Whitledge TE (1983) Production and transport of phytoplankton biomass over the continental shelf of the New York Bight. Continental Shelf Res 1:305-337

Margalef R, Durán M, Sáiz F (1955) El fitoplancton de la Ría de Vigo de enero de 1953 a marzo de 1954. Investigación pesq. 2:85-129

Martin-Jézéquel V (1992) Effect of Si-status on diel variation of intracellular free amino acids in Thalassiosira weissflogii under low-light intensity. In: Berman T, Gons HJ, Mur LR (eds) The daily growth cycle of phytoplankton, Hydrobiologia 238:159-167 
Moal J, Martin-Jézéquel V, Harris RP, Samain JF, Poulet SA (1987) Interspecific and intraspecific variability of the chemical composition of marine phytoplankton. Oceanol Acta 3:339-346

Moore JK, Villareal TA (1996) Byoyancy and growth characteristics of three positively buoyant marine diatoms. Mar Ecol Prog Ser 132:203-213.

Morris I (1981) Photosynthesis products, physiological state, and phytoplankton growth. In: Platt T (ed) Physiological bases of phytoplankton ecology. Can Bull Fish aquat Sc 210:83-102

Morris I, Skea W (1978) Products of photosynthesis in natural populations of marine phytoplankton from the gulf of Maine. Mar Biol 47:303-312

Mouriño C, Fraga F (1985) Determinación de nitratos en agua de mar. Invest pesq 49:81-96

Nelson DM, Tréguer P, Brzezinski MA, Leynaert A, Quéguiner (1995) Production and dissolution of biogenic silica in the ocean: revised global estimates, comparison with regional data and relationship to biogenic sedimentation. Global Biogeochemical Cycles 9:359-372

Officer CB, Ryther JH (1980) The possible importance of silicon in marine eutrophication. Mar Ecol Prog Ser 3:83-91

Paasche E, Bryceson I, Tangen K (1984) Interspecific variation in dark nitrogen uptake by dinoflagellates. J Phycol 20: 394-401

Passow U (1991) Vertical migration of Gonyaulax catenata and Mesodinium rubrum Mar Biol 110:455-463

Pazos Y, Figueiras FG, Alvarez-Salgado XA, Rosón G (1995) The control of succession in red tide species in the Ría de Arousa (NW Spain) by upwelling and stability. In: Lassus P, Arzul G, Erad E, Gentien P, Marcaillou C (eds) Harmful Algal Blooms. Lavoisier, Intercept Ltd, pp 645-650 
Pérez FF, Alvarez-Salgado XA, Rosón G, Ríos AF (1992) Carbonic-calcium system, nutrients and total organic nitrogen in continental runoff to the Galician Rías Baixas, NW Spain. Oceanol Acta 15: 595-602

Prego R (1992) Flows and budgets of nutrient salts and organic carbon in relation to a red tide in the Ría of Vigo (NW Spain). Mar Ecol Prog Ser 79:289-302

Prego R, Fraga F (1992) A simple model to calculate the residual flows in a Spanish ría. Hydrographic consequences in the Ría of Vigo. Estuar Coast Shelf Sci $34: 603-615$

Pingree RD, Holligan PM, Mardell GT, Head RN (1976) Influence of physical stability on spring-summer and autumn phytoplankton blooms in the Celtic Sea. J Mar Biol Ass UK 56: 845-873

Platt T, Harrison WG, Lewis MR, Li WKW, Sathyendranath S, Smith RE, Vezina AF (1989) Biological production of the oceans: the case for a consensus. Mar Ecol Prog Ser 52:77-88

Pritchard DW (1969) Dispersion and flushing of pollutants in estuaries. J Hydraul Div Am Soc Civil Eng 95 115-124

Pugh DT (1987) Tides, surges and mean sea level. John Wiley, London

Quiñones RA, Platt T (1991) The relationship between the $f$-ratio and the P:R ratio in the pelagic ecosystem. Limnol Oceanogr 36:211-213

Richardson TL, Cullen JJ (1995) Changes in buoyancy and chemical composition during growth of a coastal marine diatom: ecological and biogeochemical consequences. Mar Ecol prog Ser 128:77-90.

Ríos AF, Nombela MA, Pérez FF, Rosón G, Fraga F (1992) Calculation of runoff to an estuary. Ría de Vigo. Scient Mar 56(1):29-33

Ríos AF, Fraga F, Figueiras FG, Pérez FF (1995) New and regenerated production in relation to the proliferation of diatoms and dinoflagellates in natural conditions. In: Lassus P, Arzul G, Erad E, Gentien P, Marcaillou C (eds) Harmful Algal Blooms. Lavoisier, Intercept Ltd, Paris, pp 663-668 
Rosón G, Alvarez-Salgado XA, Pérez FF (1997) A non-steady state box-model to determine residual flows in a partially mixed estuary, based on both thermohaline properties. Application to the Ría de Arousa (NW Spain). Estuar Coast Shelf Sci 44:249-262

Smayda TJ (1990) Novel and nuisance phytoplankton blooms in the sea: evidence for a global epidemic. In: Graneli E, Sundström B, Edler L, Anderson D (eds) Toxic Marine Phytoplankton. Elsevier, New York, pp 29-40

Tang EPY (1996) Why do dinoflagellates have lower growth rates?. J Phycol 32:8084

Thomas WH, Gibson CH (1990) Quantified small-scale turbulence inhibits a red tide dinoflagellate, Gonyaulax polyedra Stein. Deep-Sea Res 37:1583-1595

UNESCO (1983) Algorithms for computation of fundamental properties of seawater. UNESCO technical paper in marine sciences 44

Vincent WF (1992) The daily pattern of nitrogen uptake by phytoplankton in dynamic mixed layer environments. In: Berman T, Gons HJ, Mur LR (eds) The daily growth cycle of phytoplankton, Hydrobiologia 238:37-52

Villarino ML, Figueiras FG, Jones KJ, Alvarez-Salgado XA, Richard J, Edwards A (1995) Evidence of in situ diel vertical migration of a red-tide microplankton species in Ría de Vigo (NW Spain). Mar Biol 123:607-617

Watanabe M, Kohata k, Kimura T, Takamatsu T (1995) Generation of a Chatonella antiqua bloom by imposing a shallow nutricline in a mesocosm Limnol Oceanogr 40: $1447-1460$

Webb WL, Newton M, Starr D (1974) Carbon dioxide exchange of Alnus rubra: a mathematical model. Ecologia, 17: 281-291

Wooster WS, Bakun A, Mclain DR (1976) The seasonal upwelling cycle along the eastern boundary of the North Atlantic. J Mar Res 34: 131-141

Yamochi S, Abe T (1984) Mechanisms to initiate a Heterosigma akashiwo red tide in Osaka Bay. II. Diel vertical migration. Mar Biol 83:255-261 
Yentsch, CS, Menzel DW (1963). A method for the determination of phytoplankton chlorophyll and phaeophytin by fluorescence. Deep-Sea Res. 10: 221-231 
Figure legends

Fig. 1 Map of Ría de Vigo showing sampling site used for the in situ $24 \mathrm{~h}$ experiment on 19 and 20 September 1991

Fig. 2 Actual residual currents along main axis of Ría de Vigo obtained from array of four Aanderra current-meters deployed at 9, 19, 29 and 35 m depth (a), and depth- averaged residual currents in surface outgoing-layer ( $\underline{\mathrm{SOL}})$, intermediate ingoing-layer (Iㄴ) and bottom outgoing-layer ( $\underline{\mathrm{BOL}})(\mathbf{b})$

Fig. 3 Composite temperature-salinity diagram for 13 casts (numbered in "key") performed during in situ $24 \mathrm{~h}$ experiment. [Line Eastern North Atlantic Central Water (ENACW) from the oceanic reference station off Ría de Vigo; square on line oceanic end member at sampling site (temperature $=12.44^{\circ} \mathrm{C}$, salinity $=35.95 \mathrm{pss}$ )]

Fig. 4 Daily average upwelling-index calculated in geostrophic cell centred at $43^{\circ} \mathrm{N}$, $11^{\circ} \mathrm{W}$. Values are in $\mathrm{m}^{3} \mathrm{~s}^{-1} \mathrm{Km}^{-1}$ coast

Fig. 5 Time-course of density anomaly $\gamma=\rho(S, \theta, 0)-1000$ (where $S=$ salinity; $\theta=$ potential temperature; $0=$ atmospheric pressure) (a), nitrate (b), nitrite (c), ammonium (d), silicate (e), and dissolved oxygen (f) during in situ $24 \mathrm{~h}$ experiment. Concentrations in $\mu \mathrm{mol} \mathrm{kg}{ }^{-1}$ (Black bars on top abscissas night; $\underline{\mathrm{H}}$ high tide; $\underline{\mathrm{L}}$ low tide)

Fig. 6 Time-course of particulate organic nitrogen (PON) $\mu \underline{M}(\mathbf{a}), C: N$ molar ratio (b), diatom numbers, as \% total diatoms in water column (c), dinoflagellate numbers, as $\%$ total dinoflagellates in water column (d), chlorophyll fluorescence $\mathrm{mg} \mathrm{m}^{-3}(\mathbf{e})$, and maximum change in the quantum yield of fluorescence $\Delta \phi_{\text {sat }}(\mathbf{f})$, during the situ $24 \mathrm{~h}$ experiment (Black bars on top of abscissas night; $\underline{H}$ high tide; $\underline{L}$ low tide) 
Table 1 Geometry of Ría de Vigo at sampling site, Station 3b, and average salinity of surface outgoing-layer (SOL), intermediate ingoing-layer (IIL) and bottom outgoinglayer (BOL). Following box-model approach (Pritchard, 1969; Prego and Fraga, 1992), a cross-section (including Station 3b) perpendicular to main axis of Ría de Vigo (i.e. perpendicular to recorded currents) was taken to calculate area of each layer

\begin{tabular}{lllc}
\hline Layer & $\begin{array}{l}\text { Depth range } \\
(\mathrm{m})\end{array}$ & $\begin{array}{l}\text { Area } \\
\left(\mathrm{m}^{2}\right)\end{array}$ & $\begin{array}{l}\text { Mean salinity } \\
(\mathrm{pss})\end{array}$ \\
\hline SOL & $0-4$ & 11000 & 35.020 \\
IIL & $4-26$ & 35400 & 35.617 \\
BOL & $26-39$ & 9910 & 35.774 \\
\hline
\end{tabular}


Table 2 Photosynthesis -irradiance curve parameters: assimilation number $\left(\underline{P}_{\max }\right)$ and light saturation $\left(\underline{I_{k}}\right)$ for incubations performed during diel experiment in September 1991. ( $\underline{r}^{2}$ correlation coefficient of the $\underline{\underline{P}} \underline{\underline{l}}$ curves: $\underline{\mathrm{PAR}}$ actual underwater light intensity at sampling depths; GMT Greenwich Mean Time)

\begin{tabular}{|c|c|c|c|c|c|}
\hline $\begin{array}{l}\text { Date, } \\
\text { time (GMT) }\end{array}$ & $\begin{array}{l}\text { depth } \\
\text { (m) }\end{array}$ & $\underline{r}^{2}$ & $\frac{P_{\max }}{\left(\mathrm{mg} \mathrm{C} \mathrm{mg}^{-1} \mathrm{chl}^{\mathrm{a}} \mathrm{h}^{-1}\right)}$ & $\frac{\underline{\mathrm{I}}}{\left(\mu \mathrm{E} \mathrm{m}^{-2} \mathrm{~s}^{-1}\right)}$ & 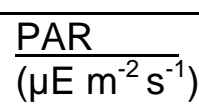 \\
\hline \multicolumn{6}{|l|}{19 Sep } \\
\hline \multirow[t]{3}{*}{$10: 52$} & 0 & 0.99 & 11.35 & 762 & 676 \\
\hline & 5 & 0.99 & 7.64 & 287 & 145 \\
\hline & 12 & 0.95 & 5.04 & 244 & 17 \\
\hline \multirow[t]{2}{*}{$14: 20$} & 2 & 1.00 & 14.68 & 990 & 203 \\
\hline & 7 & 0.99 & 4.26 & 428 & 51 \\
\hline \multirow[t]{2}{*}{$15: 56$} & 0 & 0.98 & 4.84 & 328 & 877 \\
\hline & 5 & 0.98 & 4.51 & 373 & 123 \\
\hline \multicolumn{6}{|l|}{20 Sep } \\
\hline \multirow[t]{2}{*}{ 08:18 } & 0 & 0.99 & 9.62 & 463 & 153 \\
\hline & 5 & 0.99 & 6.55 & 289 & 57 \\
\hline \multirow[t]{2}{*}{ 09:40 } & 0 & 1.00 & 10.11 & 295 & 137 \\
\hline & 5 & 0.98 & 5.60 & 278 & 58 \\
\hline
\end{tabular}




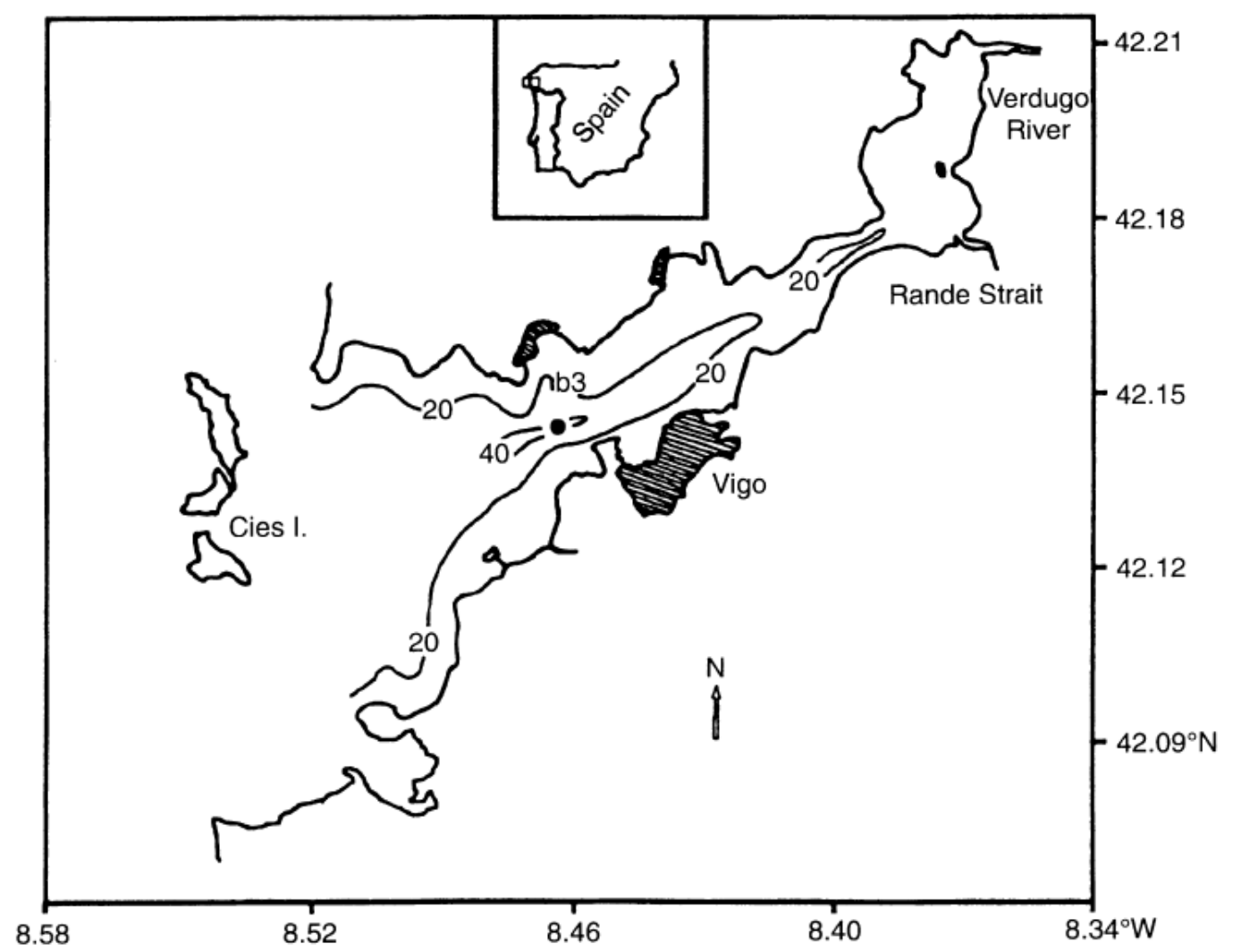

Figure 1 


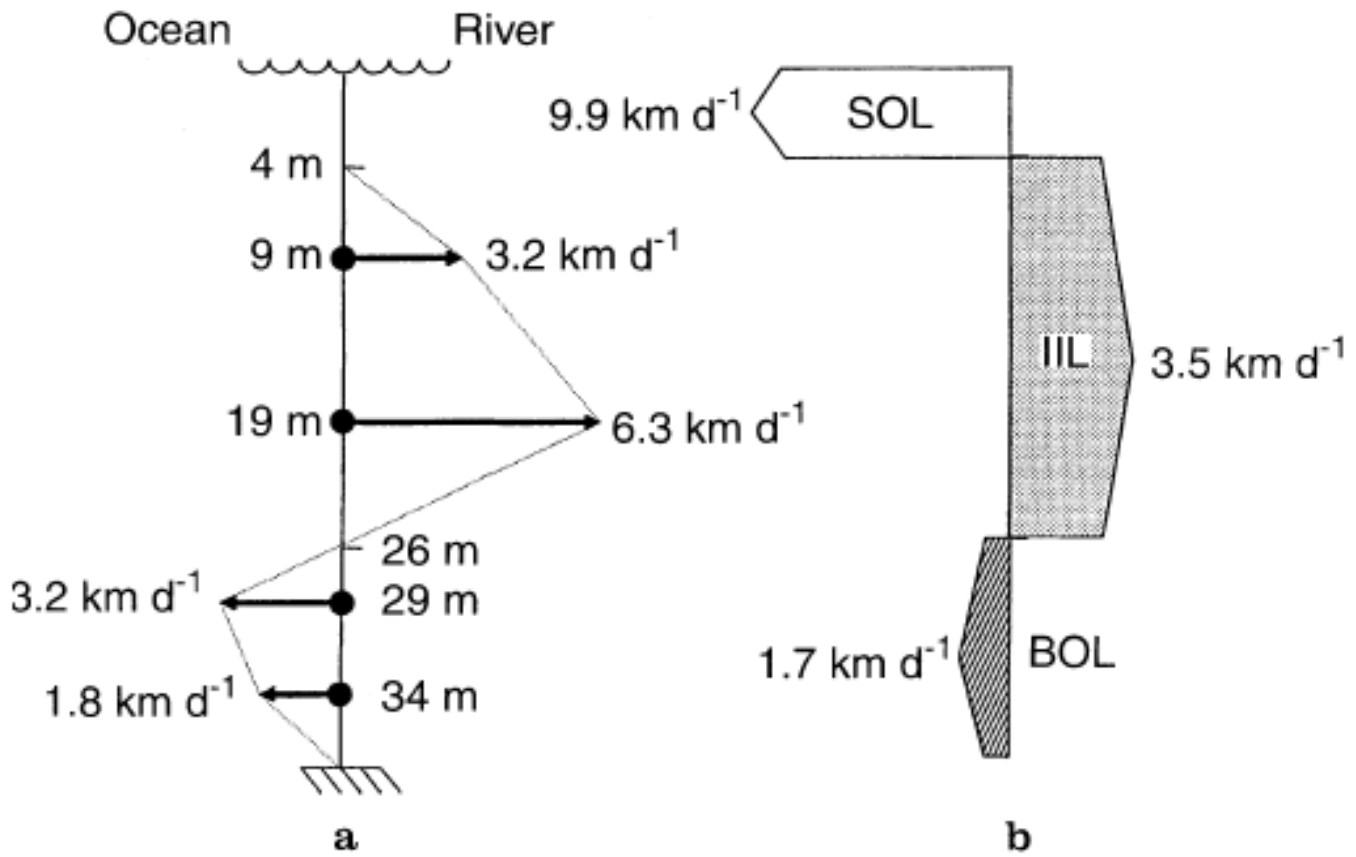

Figure 2 


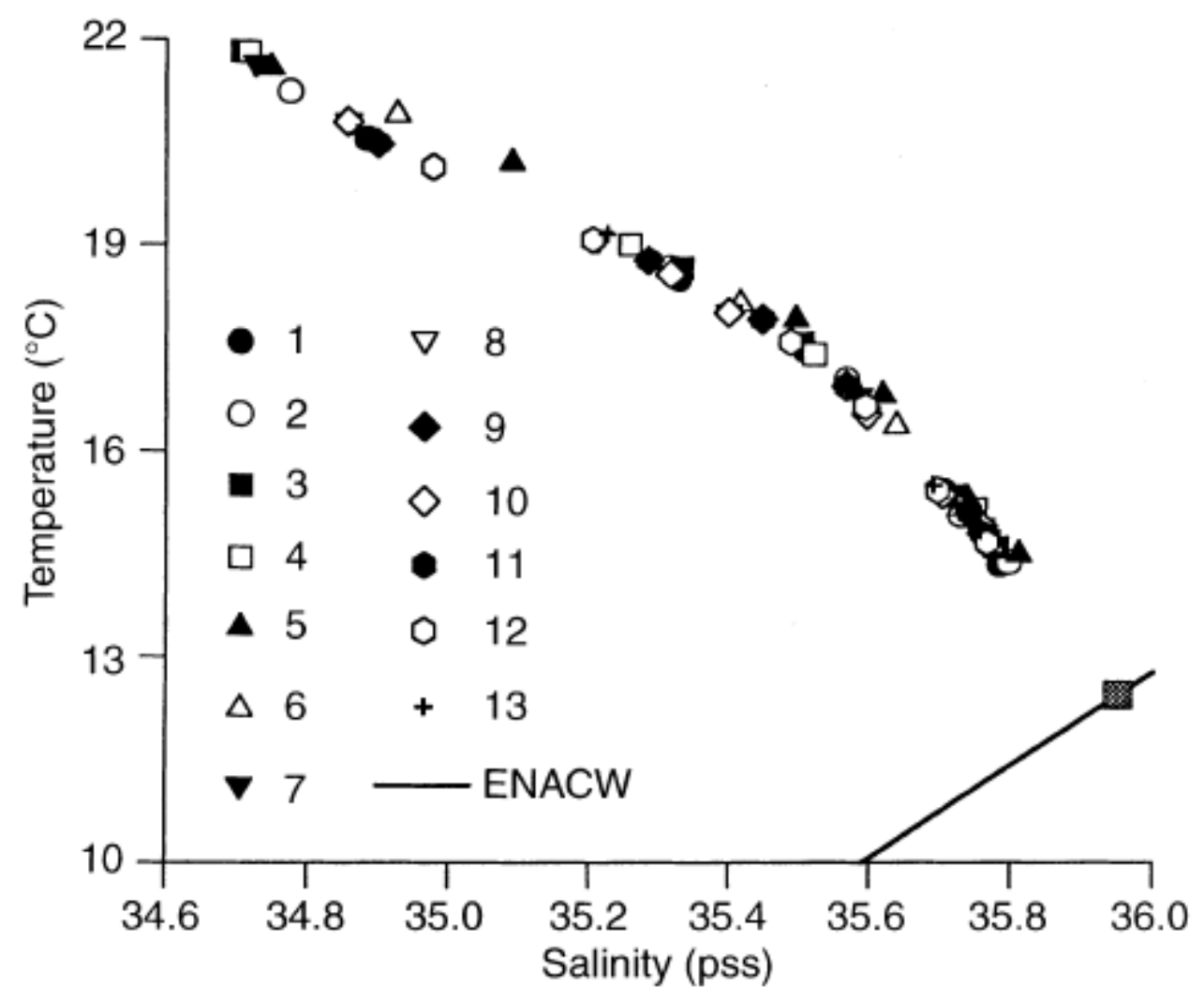

Figure 3 


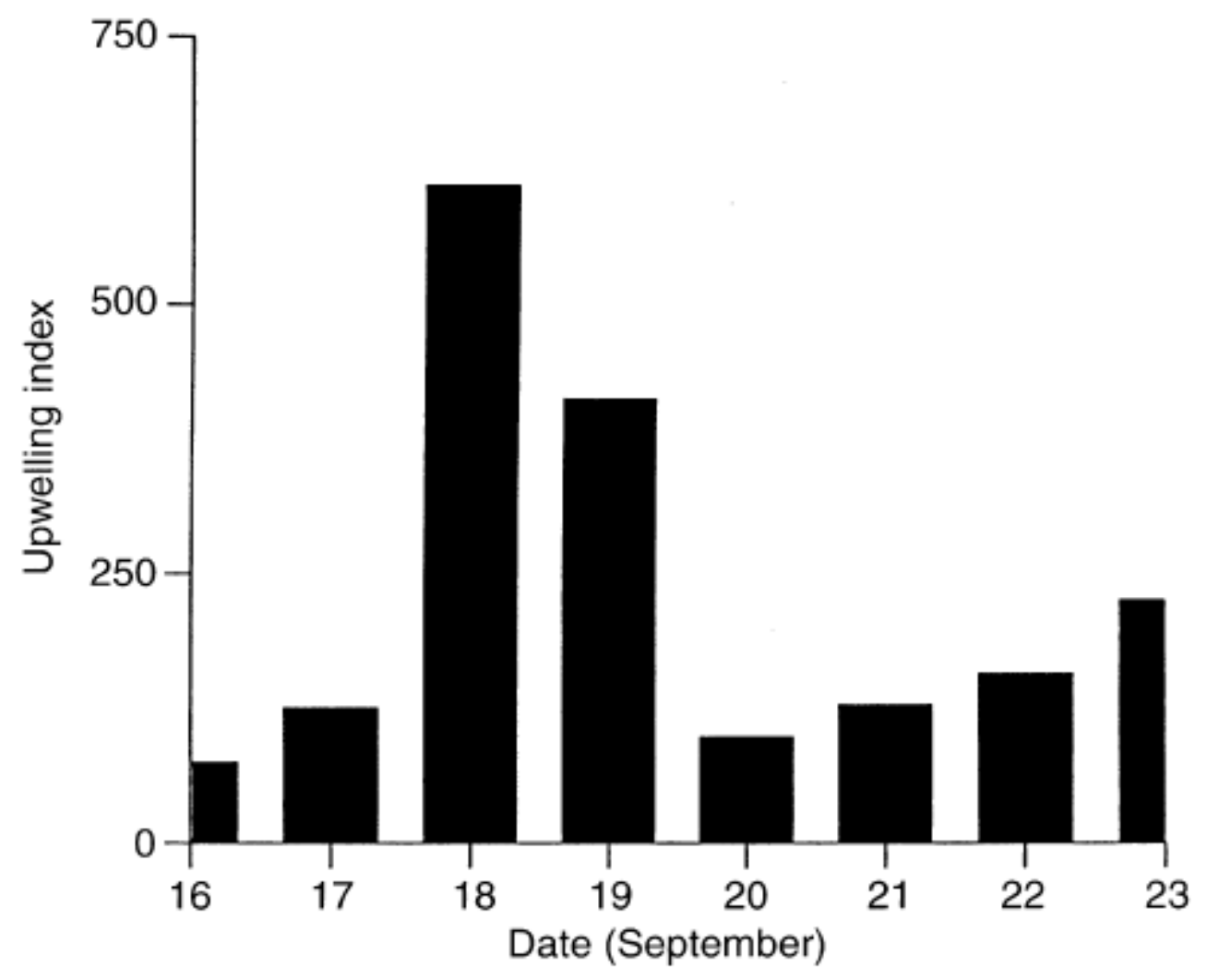

Figure 4 

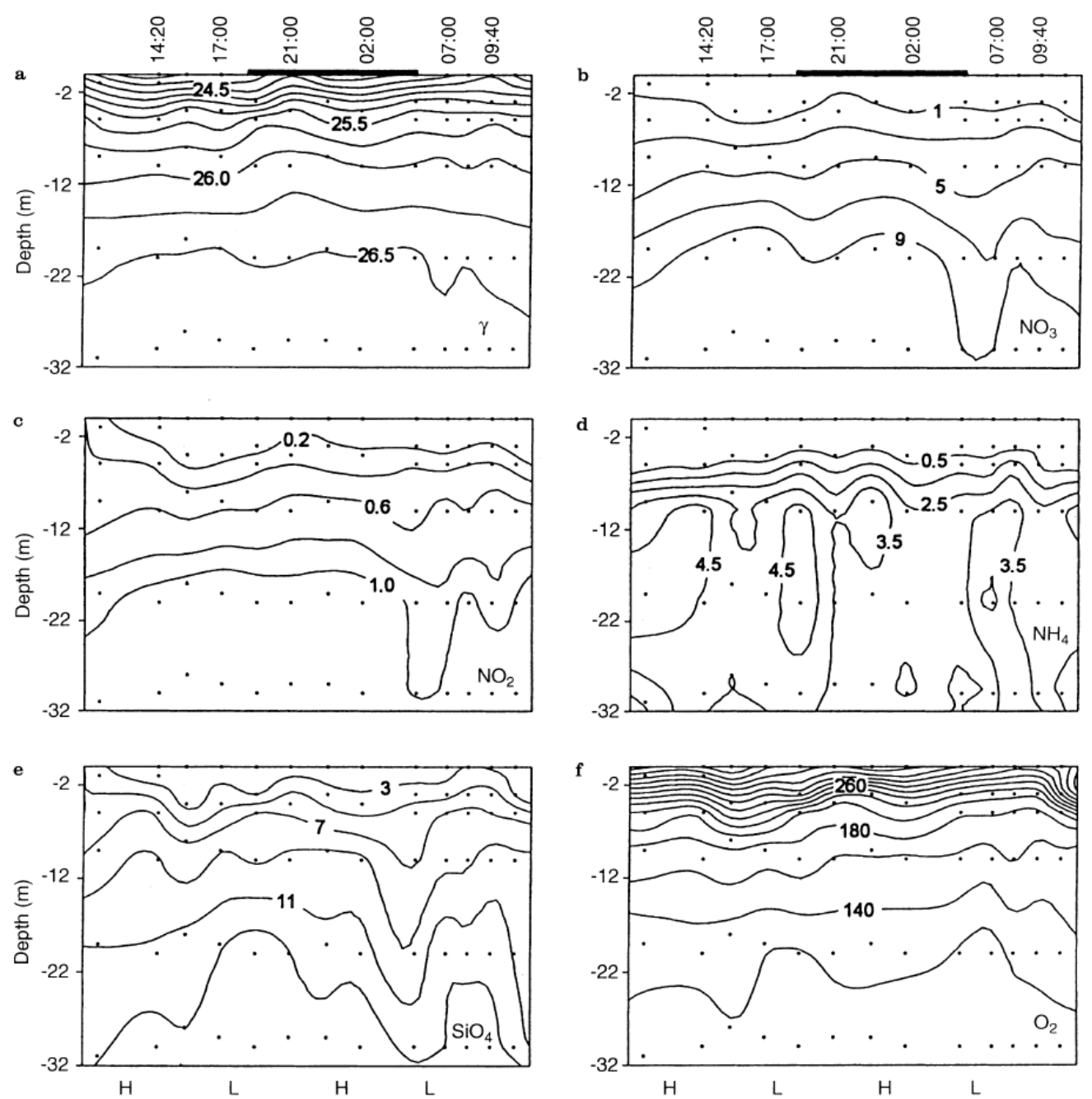

Figure 5 

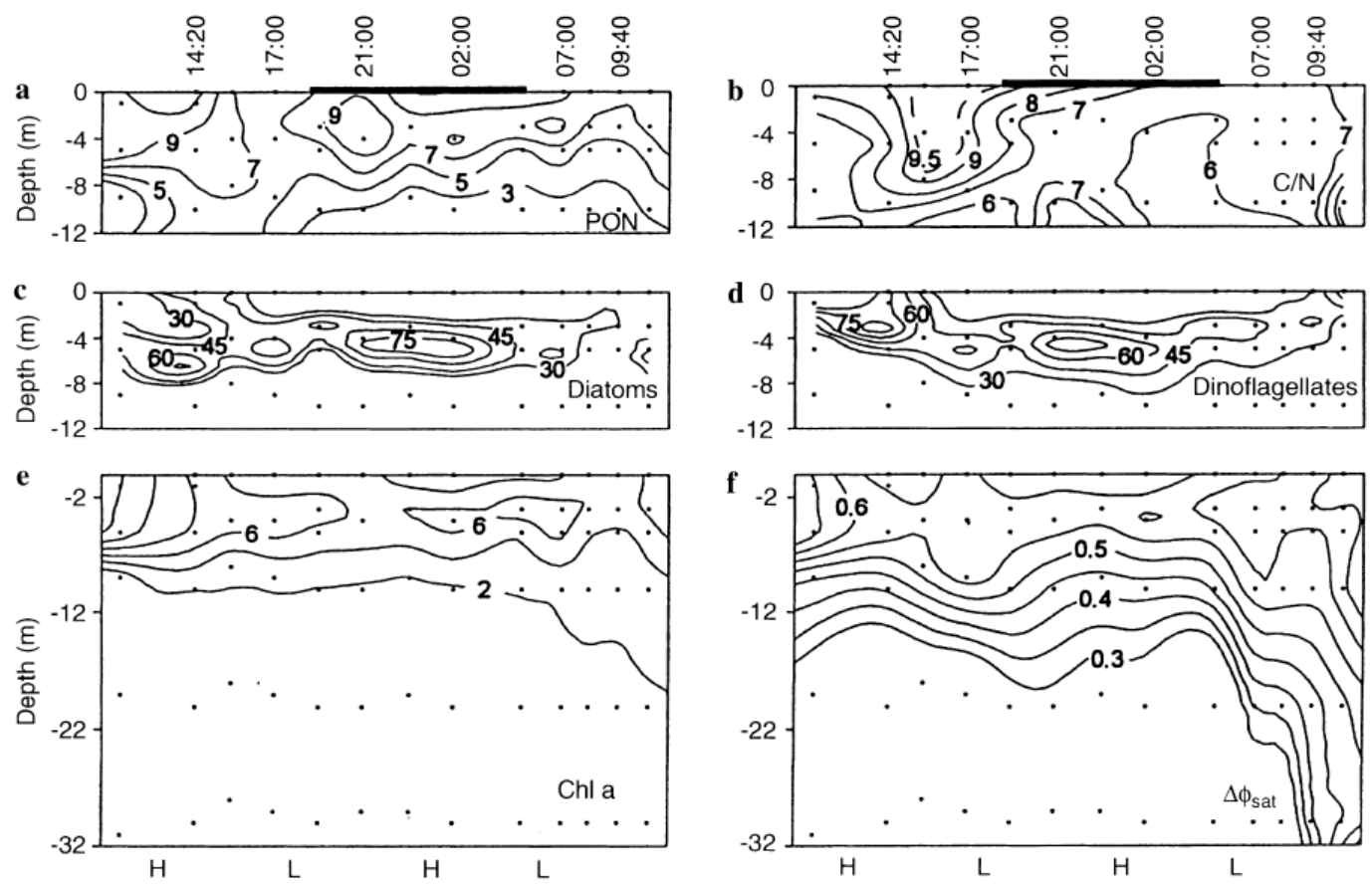

Figure 6 